\title{
Release of alkali metals during co-firing biomass and coal
}

\author{
Dongyin $\mathrm{Wu}^{\mathrm{a}}$, Yuhao Wang ${ }^{\mathrm{a}, \mathrm{b}}$, Yang Wang ${ }^{\mathrm{c}}$, Sen $\mathrm{Li}^{\mathrm{b}}$, Xiaolin Wei ${ }^{\mathrm{b}, *}$ \\ a School of Energy and Power Engineering, Xi'an Jiaotong University, Xi'an 710049, China \\ b State Key Laboratory of High Temperature Gas Dynamics, Institute of Mechanics, Chinese Academy of Sciences, Beijing 100190, China \\ ${ }^{c}$ Aerospace Research Institute of Special Material and Processing Technology, Beijing 100074, China
}

\section{A R T I C L E I N F O}

\section{Article history:}

Received 15 July 2015

Received in revised form

14 April 2016

Accepted 19 April 2016

Available online 3 May 2016

\section{Keywords:}

Release

Alkali metals

Co-firing

Biomass

\begin{abstract}
A B S T R A C T
The release of alkali metals is investigated by means of ash element measurement and chemical equilibrium calculation during co-firing biomass (cornstalk derived fuel) and coal. The experiments are operated under different mass blending fraction and temperature conditions. With increasing cornstalk fraction, the normalized ash content decreases according to a quadratic curve because the formation of alkali aluminosilicate may result in more elements being retained in ash. Similarly, the release ratios of K, $\mathrm{Na}$, and $\mathrm{S}$ do not change linearly with the variation of cornstalk fraction either, which are suppressed significantly by the interaction of biomass and coal ashes. For the effect of $\mathrm{CaO}$ additive, the release ratios of $\mathrm{K}$ and $\mathrm{Na}$ increase with its enhancement. The equilibrium analysis is used to predict and evaluate the release of alkali metals. The release of alkali metals enhances with the increase of temperature and cornstalk fraction. For silicon-lean blending fuels, adding Ca will decrease $\mathrm{HCl}(\mathrm{g})$ and release more $\mathrm{KCl}(\mathrm{g})$ and $\mathrm{KOH}(\mathrm{g})$ in both fuel-rich and air-rich conditions. More $\mathrm{KCl}(\mathrm{g})$ and $\mathrm{NaCl}(\mathrm{g})$ will be formed with increasing $\mathrm{Ca} /(\mathrm{S}+0.5 \mathrm{Cl})$ ratio due to the formation of $\mathrm{CaSiO}_{3}(\mathrm{~s})$ and the reduction of alkali aluminosilicate.
\end{abstract}

(c) 2016 Elsevier Ltd. All rights reserved.

\section{Introduction}

In recent years, co-firing of biomass and coal has been a hot spot in the field of electricity generation [1-6]. The thermal utilization of biomass, as a substitute or supplement to conventional fossil fuels, not only decreases $\mathrm{CO}_{2}$ emission in power plants, but also reduces a certain amount of $\mathrm{NO}_{\mathrm{x}}$ and $\mathrm{SO}_{\mathrm{x}}$ emissions due to the lower content of $\mathrm{N}$ and $\mathrm{S}$ in biomass [7-9].

Biomass contains high quantities of $\mathrm{K}$, $\mathrm{Na}$ and $\mathrm{Cl}$ compared with coal. During burning large quantities of biomass, alkali chlorides are released through vaporization. And the gaseous species may subsequently participate in chemical reactions or physical transformations, condensing to form fly ash or aerosols, and finally deposit on heat transfer surfaces [10-14]. Due to the interaction of chlorine and alkali metals in the ash and gas, the complex metal reactions will occur and results in severe corrosion on heat transfer surfaces [10]. Some experimental data have been reported on the ash deposition during biomass combustion [15-17]. Generally, the deposition is caused by condensation, impact of large particles

\footnotetext{
* Corresponding author.

E-mail address: xlwei@imech.ac.cn (X. Wei).
}

( $>10 \mu \mathrm{m})$, and thermophoresis of small particles $(<10 \mu \mathrm{m})$. The lower melting point for some $\mathrm{K}$ species (e.g. $\mathrm{KCl}$ melts at $1044 \mathrm{~K}$ ) implies a high risk of deposition on furnace walls and convection tubes. Thus, fuel ash has been investigated to prevent the release of gaseous alkali-metal compounds [18-21].

The release of gaseous alkali metals during combustion can be measured by direct sampling, surface ionization detector, molecular beam mass spectrometer (MBMS), on-line excimer laser induced fragmentation fluorescence (ELIF), laser-induced breakdown spectroscopy (LIBS), and in-situ alkali chloride monitor (IACM), etc. [22-26]. Monkhouse [22] reviewed on-line systems for detection of metals, particularly alkali metals, such as $\mathrm{K}$ and $\mathrm{Na}$ in combustion and pyrolysis gases. Porbatzki et al. [23] used MBMS to measure the release of alkali metals, chlorine and sulfur of four different types of biomass, and they found that the release of inorganic species like $\mathrm{HCl}, \mathrm{KCl}$ and $\mathrm{H}_{2} \mathrm{~S}$ are strongly dependent on other inorganic constituents in the samples (e.g. Si and Ca). Erbel et al. [24] described the first on-line, in-situ measurement of alkali species in biomass gasification using ELIF. Fatehi et al. [25] studied on a joint numerical and experimental investigation of the release of $\mathrm{K}$ from biomass during gasification process. In their work, LIBS was adopted to measure the concentration of $\mathrm{K}$ in biomass. Forsberg et al. [26] developed IACM for measurement of alkali chlorides 
in hot flue gas, and they also described the principle and calibration of IACM.

Yang et al. [27] investigated the effect of coal sulfur on the behavior of alkali metals during co-firing biomass and coal. The results show that $\mathrm{FeS}_{2}$ addition significantly enhances the formation of potassium sulfate when $\mathrm{S} / \mathrm{K}$ molar ratio is less than two. Meanwhile, increasing $\mathrm{FeS}_{2}$ dosage reduces the formation of $\mathrm{KCl}(\mathrm{g})$ and $\mathrm{KOH}(\mathrm{g})$, and increases the release of $\mathrm{HCl}(\mathrm{g})$. Novakovic et al. [28] studied the release of potassium in $\mathrm{K}-\mathrm{Ca}-\mathrm{Si}$ and $\mathrm{K}-\mathrm{Ca}-\mathrm{P}$ systems, respectively. The results indicated that the presence of water in the gas flow enhances the K-release rate significantly. Rahim et al. [29] investigated the $\mathrm{Cl}$ release during slow pyrolysis of $\mathrm{NaCl}$-loaded cellulose in the temperature range of $150-400{ }^{\circ} \mathrm{C}$, providing new data to better understand the low-temperature $\mathrm{Cl}$ release during biomass pyrolysis. Johansen et al. [30] studied the release of $\mathrm{K}, \mathrm{Cl}$ and $\mathrm{S}$ during combustion of high-chlorine biomass in bench and pilot scale bed. W. Li et al. [31] examined the release behavior of alkali and alkaline-earth metals during oxy-fuel combustion in different gas environments. The results showed that the release rates of $\mathrm{Na}$ and $\mathrm{K}$ are higher than $\mathrm{Ca}$ and $\mathrm{Mg}$ in all types of gas environments. R. Li et al. [19] investigated the effects of temperature on the release and transformation of alkali metal species during co-combustion of coal and sulfur-rich wheat straw. The results indicated that the amounts of $\mathrm{K}$ and $\mathrm{Na}$ during co-combustion can be reduced by $\mathrm{Fe}, \mathrm{Ti}, \mathrm{S}, \mathrm{Si}$ and $\mathrm{Al}$ in blended fuels.

The aim of this study is to obtain quantitative data on the release of alkali metals during co-firing of biomass and coal using ash element measurement. Biomass and coal are co-fired under different mass blending fraction and temperature conditions. And the effect of $\mathrm{CaO}$ additive used for desulfurization on alkali metal release is also investigated. Moreover, chemical equilibrium analysis is used to predict and evaluate the behavior of alkali metals.

\section{Methods}

\subsection{Element and ash analysis}

In the experiment, one bituminous coal (Shenmu coal) and one biomass (cornstalk derived fuel) are heated to prepare ash samples.

Table 1 shows the fuel properties of coal and cornstalk derived fuel, which indicates that $\mathrm{Cl}$ content in cornstalk is obviously higher than that in coal. However, coal has higher sulfur and ash content than cornstalk. Table 2 shows the ash composition of coal and cornstalk after combustion. $\mathrm{K}$ content in cornstalk ash is apparently much higher than that in coal ash, and this may due to the necessity of $\mathrm{K}$ for plant growing. Cornstalk ash also has high Si content. The content of $\mathrm{Al}, \mathrm{S}$ and $\mathrm{Ca}$ in coal ash are higher than those in cornstalk ash. In the process of combustion, Al can react with $\mathrm{Si}$ to form aluminosilicate, and $\mathrm{S}$ can oxidize to form sulfate. Ca can form $\mathrm{CaSO}_{4}$ when $\mathrm{Ca}$ content is high enough, and adding $\mathrm{CaO}$ to absorb $\mathrm{S}$ is often used reduce the emission of $\mathrm{SO}_{2}$. Table 3 shows the content of $\mathrm{Ca}, \mathrm{K}, \mathrm{Na}, \mathrm{S}$, and $\mathrm{P}$ in cornstalk, which is analyzed directly by inductively coupled plasma-atomic emission spectroscopy (ICPAES). In addition, the element content of coal given in Table 3 is calculated by the ash composition in Table 2 .

\subsection{Experimental apparatus and methods}

To investigate the change of ash content during co-firing coal and cornstalk derived fuel, the experiment is operated in a SK2-512 medium temperature box-type resistance furnace with power of $5 \mathrm{~kW}$ and rated temperature of $1200^{\circ} \mathrm{C}$. A SR1 series PID temperature controller, made by SHIMADEN, is used to regulate the temperature. The size distribution of coal and biomass is in the range of $0-0.2 \mathrm{~mm}$. The bed thickness is approximately $5-10 \mathrm{~mm}$ at steady condition. Before the preparation of ash samples, pulverized coal and cornstalk are blended into different required ratios. Then 20-30 g pulverized blending fuel is heated to $573 \mathrm{~K}$ and kept for $30 \mathrm{~min}$ in the resistance furnace at air condition. Subsequently, the blending fuel is heated to $1073 \mathrm{~K}$ or $1273 \mathrm{~K}$ with the heating rate of $10 \mathrm{~K} / \mathrm{min}$ and kept for $1 \mathrm{~h}$ to obtain ash samples. The ash content is calculated according to the mass of fuel and ash. Finally, ash samples are analyzed by ICP-AES to measure the content of $\mathrm{Ca}, \mathrm{K}, \mathrm{Na}, \mathrm{S}$, and $\mathrm{P}$ in ash. X-ray diffraction (XRD) is used to detect the sorts of the compounds.

\subsection{Calculating methods}

Chemical equilibrium analysis is widely used to predict chemical forms at thermodynamic stable state during combustion. The composition is calculated by minimizing the total Gibbs free energy in the combustion system [33]. Thermodynamic equilibrium implies the minimum total Gibbs free energy, where homogeneous and heterogeneous reactions all reach equilibrium. In this paper, the equilibrium analysis software FactSage is used to analyze the release of alkali metals during co-firing cornstalk derived fuel and coal. Based on its large database, all the elements will be considered into the calculation. After entering parameters (elementary composition of fuel and air, temperature and pressure etc.), FactSage will search the corresponding species and elements from the database automatically. Then the thermodynamic equilibrium calculation is conducted for the system with these species. The elements C, H, O, N, S, Cl, Si, P, Ca, K, Na, Mg, Al, Fe, and Ti are used to present the original fuel. 600 species (143 gas, 87 liquid and 370 solid species) are selected to conduct the equilibrium analysis calculation. The temperature range is between 400 and $2000 \mathrm{~K}$, and the calculated point is set every $50 \mathrm{~K}$. Although FactSage is powerful in predicting stable species during chemical equilibrium process, it still has some deficiencies in combustion calculation [33,34]. For example, the reaction time at practical condition is not long enough to reach thermodynamic equilibrium. In general, FactSage can only be used to give the equilibrium distribution of elements and the reaction mechanism of species.

\section{Results and discussion}

\subsection{Main compounds in ash}

$\mathrm{XRD}$ is used to analyze the main compounds in ash produced by co-firing cornstalk derived fuel and coal (Fig. 1). Alkali metals in coal ash occur as $\mathrm{KAlSi}_{3} \mathrm{O}_{8}, \mathrm{NaAlSi}_{3} \mathrm{O}_{8}$, and $\mathrm{Na}_{2} \mathrm{SO}_{4}$. And they occur in cornstalk ash as $\mathrm{KFeO}_{2}, \mathrm{~K}_{6} \mathrm{Fe}_{2} \mathrm{O}_{5}, \mathrm{~K}_{2} \mathrm{~S}_{2} \mathrm{O}_{5}, \mathrm{NaCl}$, and $\mathrm{Na}_{3} \mathrm{PO}_{4}$.

Table 1

Fuel properties.

\begin{tabular}{|c|c|c|c|c|c|c|c|c|}
\hline \multirow[t]{2}{*}{ Fuel } & \multicolumn{8}{|c|}{ Ultimate analysis (wt\%, air-dried basis) } \\
\hline & $\mathrm{C}$ & $\mathrm{H}$ & 0 & $\mathrm{~N}$ & $\mathrm{~S}$ & $\mathrm{Cl}$ & Ash & Moisture \\
\hline Coal & 67.04 & 3.69 & 13.29 & 1.28 & 0.44 & 0.012 & 9.10 & 5.21 \\
\hline Cornstalk derived fuel & 44.54 & 5.77 & 40.15 & 1.10 & 0.16 & 0.338 & 3.36 & 3.16 \\
\hline
\end{tabular}


Table 2

Ash composition.

\begin{tabular}{|c|c|c|c|c|c|c|c|c|c|c|}
\hline \multirow[t]{2}{*}{ Fuel } & \multicolumn{10}{|c|}{ Ash basis (wt\%) } \\
\hline & $\mathrm{SiO}_{2}$ & $\mathrm{Al}_{2} \mathrm{O}_{3}$ & $\mathrm{Fe}_{2} \mathrm{O}_{3}$ & $\mathrm{CaO}$ & $\mathrm{MgO}$ & $\mathrm{K}_{2} \mathrm{O}$ & $\mathrm{Na}_{2} \mathrm{O}$ & $\mathrm{TiO}_{2}$ & $\mathrm{SO}_{3}$ & $\mathrm{P}_{2} \mathrm{O}_{5}$ \\
\hline Coal & 31.34 & 10.94 & 17.52 & 22.02 & 1.17 & 0.78 & 1.84 & 0.5 & 8.14 & 0.07 \\
\hline Cornstalk derived fuel & 38.38 & 4.93 & 3.94 & 7.40 & 5.69 & 24.04 & 1.15 & 0.17 & 1.64 & 3.09 \\
\hline
\end{tabular}

Table 3

Element content in biomass and coal.

\begin{tabular}{llllll}
\hline \multirow{2}{*}{ Fuel } & \multicolumn{6}{l}{ Content of element (wt\%, air-dried basis) } \\
\cline { 2 - 6 } & $\mathrm{Ca}$ & $\mathrm{K}$ & $\mathrm{Na}$ & $\mathrm{S}$ & $\mathrm{P}$ \\
\hline Coal & 1.432 & 0.059 & 0.124 & 0.737 & 0.003 \\
Cornstalk derived fuel & 0.157 & 1.112 & 0.031 & 0.136 & 0.052 \\
\hline
\end{tabular}

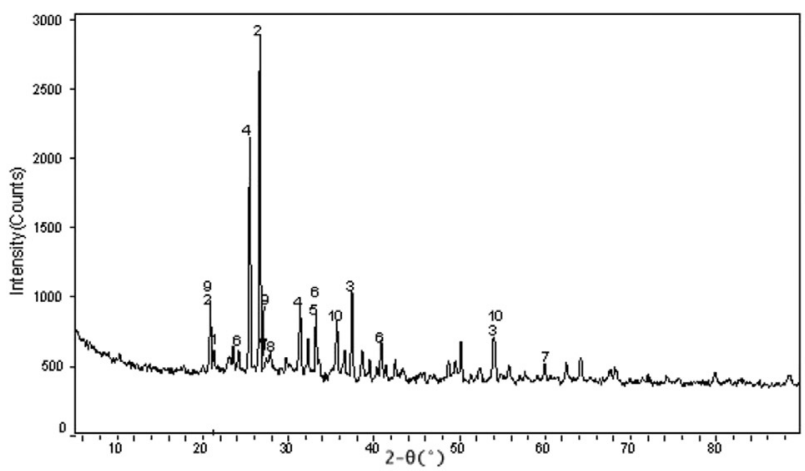

(a) coal ash
$\overline{A_{i}}=\frac{A_{i}-A_{5}}{A_{1}-A_{5}}$

where $A_{i}$ is ash content for various biomass fractions, and $A_{1}, A_{5}$ are ash content at 0 and 1.0 biomass fractions.

Fig. 2 indicates that the normalized ash content during the co-

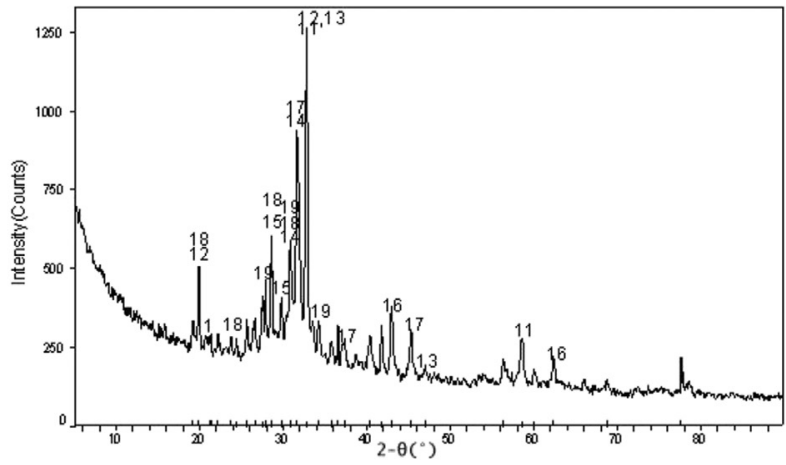

(b) cornstalk ash

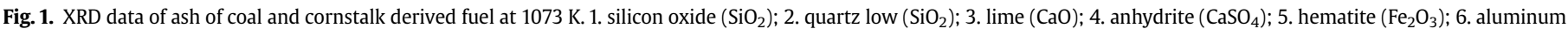

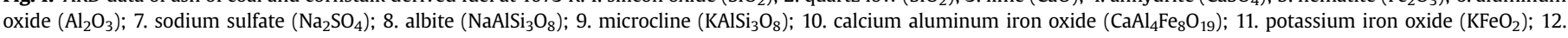

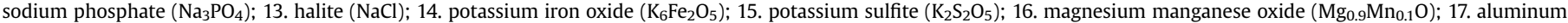
oxide $\left(\mathrm{Al}_{2} \mathrm{O}_{3}\right)$; 18. calcium chlorate hydrate $\left(\mathrm{Ca}\left(\mathrm{ClO}_{4}\right)_{2} \cdot 3 \mathrm{H}_{2} \mathrm{O}\right) ; 19$. whitlockite $\left(\mathrm{Ca}_{3}\left(\mathrm{PO}_{4}\right)_{2}\right)$.

Because of the high content of $\mathrm{Al}$ in coal ash, alkali aluminosilicate, which has a high ash melting point, is formed. However, for biomass ash, the compounds containing alkali metals have lower ash melting point, which is part of the reason for that burning biomass is easy to induce furnace slagging and fouling. Therefore, co-firing may result in the formation of alkali aluminosilicate and the increase of ash melting point.

\subsection{Experimental results of ash content and alkali metal release}

The ash content is measured at $1073 \mathrm{~K}$ or $1273 \mathrm{~K}$ during the cofiring of cornstalk derived fuel and coal (Table 4). Because of the lower ash content in cornstalk, the total ash content of cocombustion decreases with increasing biomass fraction. Higher temperature results in lower ash content because more elements in the ash are released. The ash content can be normalized by the following formulation:

Table 4

Ash content during co-firing cornstalk derived fuel and coal.

\begin{tabular}{llll}
\hline No. & Biomass fraction & $1073 \mathrm{~K}$ & $1273 \mathrm{~K}$ \\
\hline 1 & 0 & 8.99 & 9.10 \\
2 & 0.25 & 8.80 & 8.07 \\
3 & 0.5 & 6.53 & 6.57 \\
4 & 0.75 & 5.79 & 5.12 \\
5 & 1.0 & 3.51 & 1.21 \\
\hline
\end{tabular}

firing of cornstalk derived fuel and coal decreases according to a quadratic curve with increasing cornstalk fraction as the following equation:

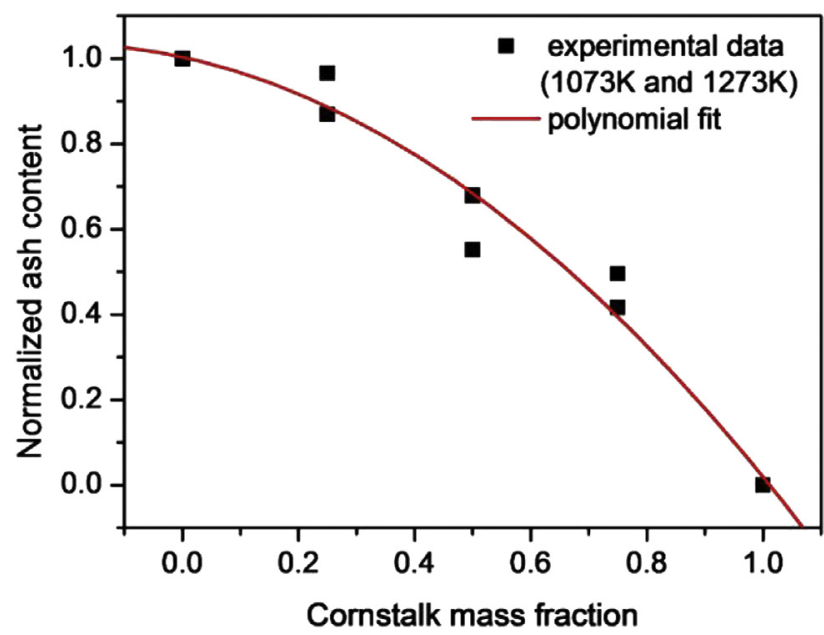

Fig. 2. Normalized ash content during co-firing. 
$\overline{A_{i}}=-0.69 B_{r}^{2}-0.29 B_{r}+1.00$

where $B_{r}$ is cornstalk fraction in the fuel blends. It is evident from Fig. 2 that the ash content does not change linearly with the increase of cornstalk fraction. This indicates that the synergistic effect between cornstalk and coal ashes occurs during the co-firing. The mineral elements in coal may result in more elements retained in ash because of the formation of alkali aluminosilicate [32]. The element content of original fuel and ash can be obtained by ICPAES. Therefore, the element release ratio $E_{r i}$ is calculated by:

$E_{r i}=1-\frac{E_{i} \cdot C_{A, i}}{E_{i, 0}}$

where $E_{i, 0}$ is element content in original fuel, $E_{i}$ is element content in ash, and $C_{A, i}$ is ash content in original fuel.

Fig. 3 shows the relationship between element release ratio and cornstalk fraction at $1273 \mathrm{~K}$ during the co-firing of cornstalk derived fuel and coal. The release ratios of $\mathrm{K}$ and $\mathrm{Na}$ are kept relatively low at the beginning and increase gradually with increasing cornstalk fraction. The curves $\mathrm{K}$ and Na don't change linearly with the variation of cornstalk fraction, which indicates that the release of alkali metals is suppressed significantly by the interaction of cornstalk and coal ashes. Potentially, more alkali aluminosilicate may be formed during the co-firing due to the high content of $\mathrm{Al}$ in coal ash, which may result in a large fraction of alkali metals retained in ash. For $\mathrm{S}$ and $\mathrm{P}$, both release ratios of $\mathrm{S}$ and $P$ firstly reduce and then increase rapidly, which implies the synergistic effect between coal and cornstalk ashes.

Fig. 4 shows the release ratios of $\mathrm{K}$ and $\mathrm{Na}$ increase with $\mathrm{CaO}$ additive at $1273 \mathrm{~K}$ during co-firing of $50 \%$ cornstalk and coal. Because the addition of $\mathrm{CaO}$ absorbs more $\mathrm{S}$ and $\mathrm{Si}$ to form more stable $\mathrm{CaSO}_{4}$ and $\mathrm{CaSiO}_{3}$ compounds, the alkali sulfate and silicate retained in ash will be reduced. As a result, more alkali metals will release into the gas phase [28]. This may be the main reason for why $\mathrm{CaO}$ additive induces higher release of alkali metals. Therefore, the increase of alkali metal release should be considered while using $\mathrm{Ca}$ addition for desulfurization.

\subsection{Equilibrium analysis of alkali metal release}

In order to validate the equilibrium analysis method on

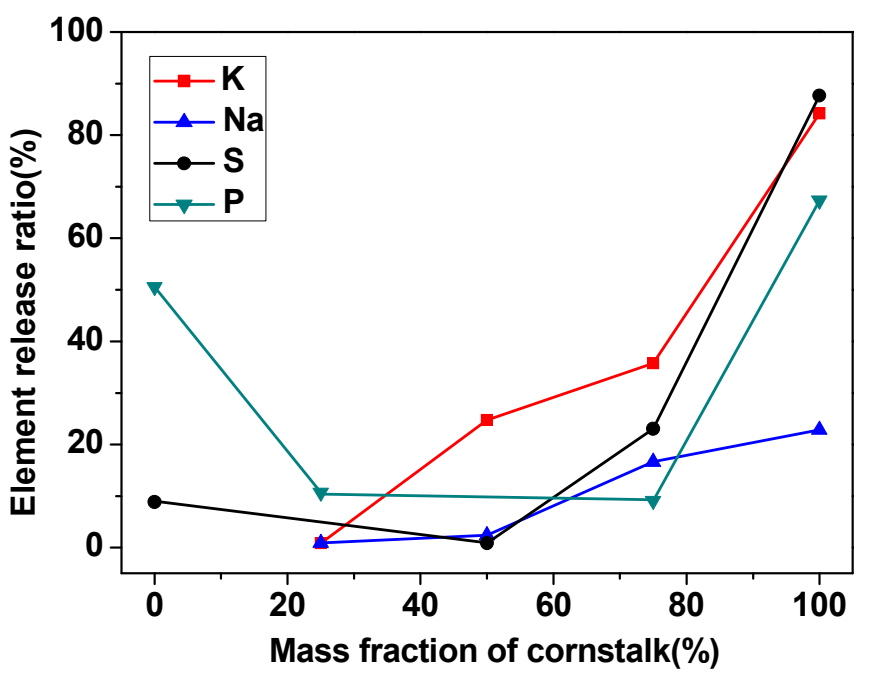

Fig. 3. Element release ratio with cornstalk fraction.

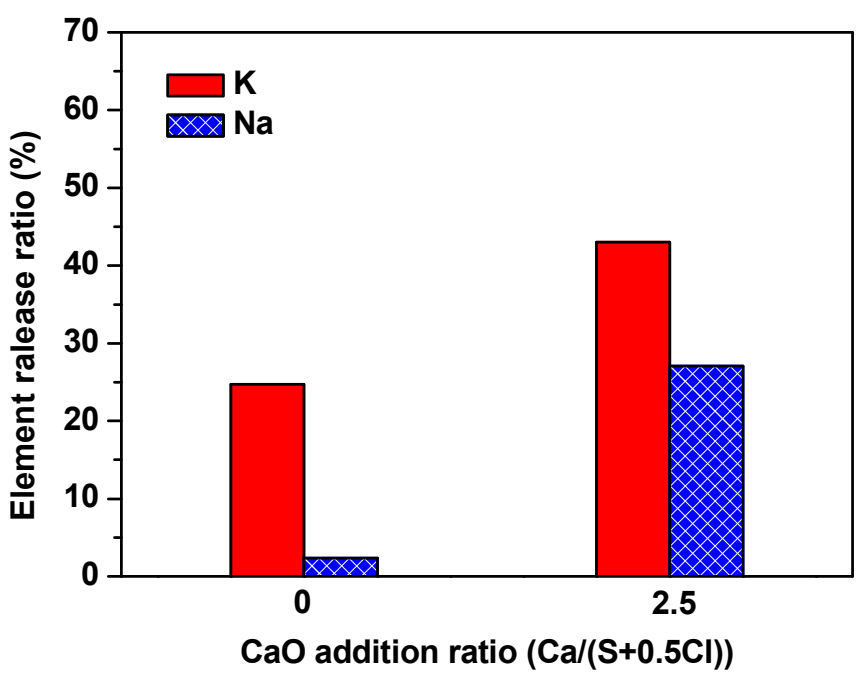

Fig. 4. Element release ratio with $\mathrm{CaO}$ addition.

researching the release of alkali metal elements, experiments are operated under the same conditions. Comparison between experimental and equilibrium analysis results on the change of element release ratios with cornstalk fraction and $\mathrm{CaO}$ additive are illustrated in Fig. 5. In Fig. 5(a), the equilibrium analysis results show that the release ratios of $\mathrm{K}$ and $\mathrm{Na}$ increase with the increase of cornstalk fraction, which are qualitatively corresponded with the experimental results. However, the release ratio of calculated $\mathrm{K}$ is higher at low cornstalk fraction and lower at high fraction than that of experimental $\mathrm{K}$, and the release ratio of calculated $\mathrm{Na}$ is much higher than that of experimental Na. In Fig. 5(b), the release ratio of calculated $\mathrm{K}$ is close to the experimental data. But the equilibrium analysis results show that the release ratio of calculated $\mathrm{Na}$ decreases with $\mathrm{CaO}$ added, deviating from the obtained trend of the experimental results. As mentioned above, the occurrences of alkali metals in coal and biomass are different. The alkali metals in cornstalk are easier to release. Moreover, the equilibrium analysis is based on unlimited long time reaction. In contrast, the experiments are time-limited and can not achieve chemical equilibrium completely, especially with high coal fraction, and the alkali metals may not be able to completely release. This is a possible reason for the deviation of $\mathrm{K}$ release ratio at low cornstalk fraction and $\mathrm{Na}$ in the whole range of calculation. With high cornstalk fraction, the easily released alkali metals in biomass may initially release as gaseous species and then condense to form fly ash on furnace walls, and not be retained in the bottom ash. These elements are treated as gaseous species, resulting in higher release ratio in the experiment, and this may be a reason for the deviation of $\mathrm{K}$ release ratio at high cornstalk fraction. In addition, some factors such as flow, mixing and diffusion may also affect the experimental results. Despite of some deviations, the equilibrium analysis can give fundamentally correct trend, which are valuable for the analysis of alkali metal release. Based on equilibrium analysis, the effects of temperature, cornstalk fraction, and $\mathrm{Ca} /(\mathrm{S}+0.5 \mathrm{Cl})$ ratio on the release of alkali metals are investigated.

Fig. 6 shows the effect of temperature on gaseous release of $\mathrm{SO}_{2} /$ $\mathrm{HCl} / \mathrm{NaCl} / \mathrm{KCl} / \mathrm{KOH}$ at various air-fuel equivalence ratios. It indicates that the air-fuel equivalence ratio has little influence on the release of $\mathrm{NaCl}(\mathrm{g})$ and $\mathrm{KOH}(\mathrm{g}) . \mathrm{HCl}$ emission increases more rapidly at a lower temperature in air-rich condition than in fuel-rich condition, and maintains the high value at a wider temperature range from about 600 to $1200 \mathrm{~K} . \mathrm{KCl}(\mathrm{g})$ starts to release at a lower temperature in fuel-rich condition. At high temperature ( $>1000 \mathrm{~K}), \mathrm{Cl}$ is released 


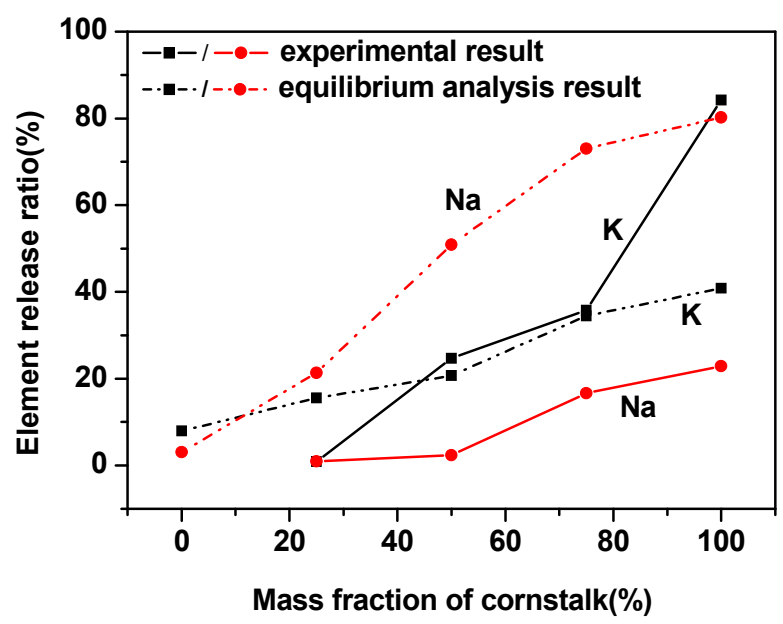

(a)

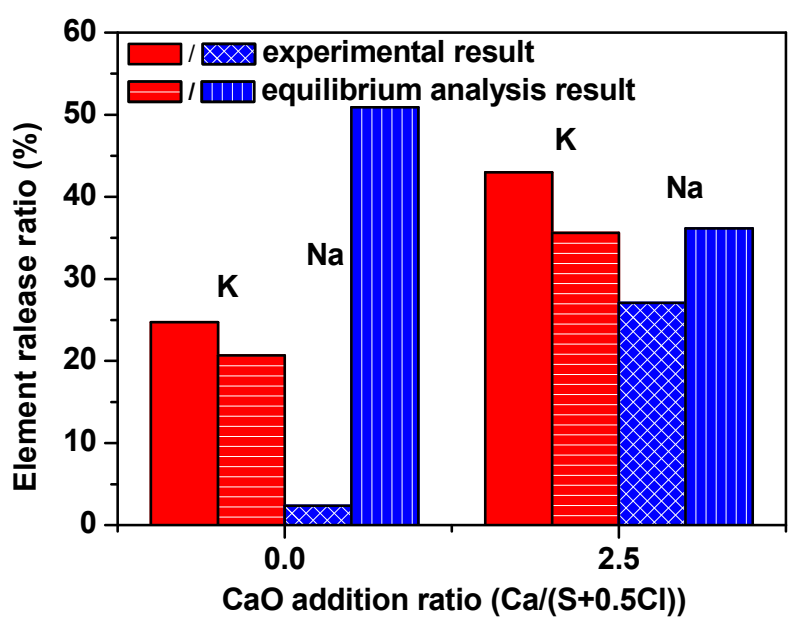

(b)

Fig. 5. Comparison between experimental and equilibrium analysis results on element release ratio with cornstalk fraction and CaO addition.

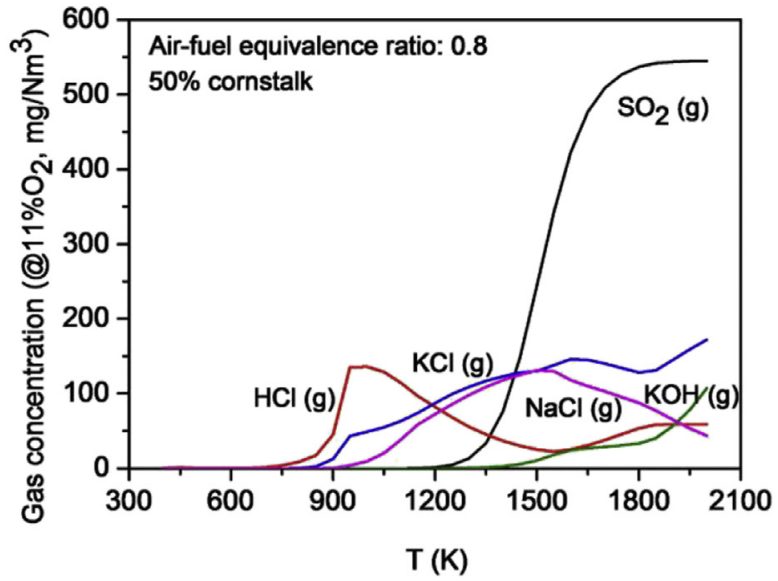

(a)

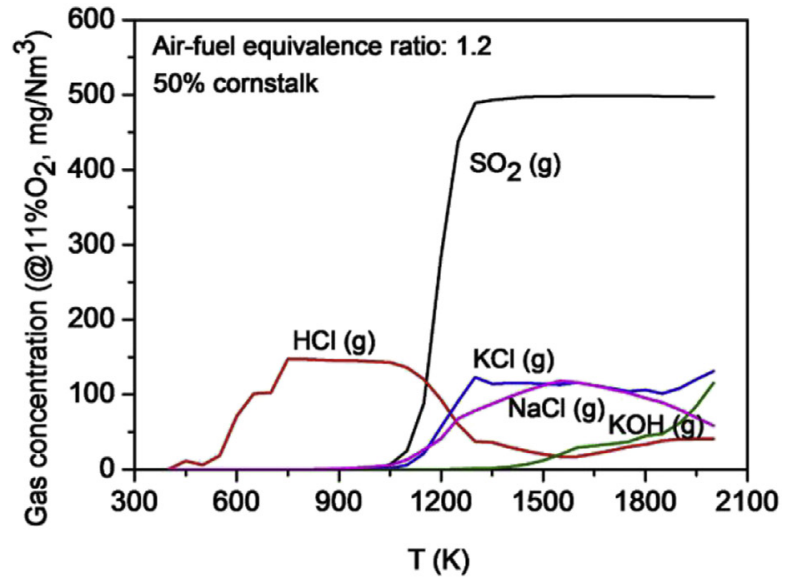

(b)

Fig. 6. The effect of temperature on the release of alkali metals and chlorine in co-firing cornstalk and coal under various air-fuel equivalence ratios.

as $\mathrm{NaCl}(\mathrm{g})$ and $\mathrm{KCl}(\mathrm{g})$. At higher temperature $(>1400 \mathrm{~K}), \mathrm{KOH}(\mathrm{g})$ is released. In the practical $\mathrm{FBC}$ or pulverized fuel combustion furnace, $\mathrm{NaCl}$ and $\mathrm{KCl}$ may release. And once gas temperature decreases enough during gas cooling, $\mathrm{NaCl}$ and $\mathrm{KCl}$ will deposit on furnace wall as solid salts which may result in metal corrosion. Thus, the release of gaseous alkali metals should be controlled during combustion.

Fig. 7 shows the effect of $\mathrm{Ca}$ additive on the release of $\mathrm{SO}_{2} / \mathrm{HCl} /$ $\mathrm{NaCl} / \mathrm{KCl} / \mathrm{KOH}$ at various temperatures. Compared with Fig. 6, Ca addition decreases $\mathrm{HCl}(\mathrm{g})$ prominently in both fuel-rich and airrich conditions. This may because $\mathrm{Ca}$ addition reacts with $\mathrm{HCl}$ to form $\mathrm{CaCl}_{2}(\mathrm{~s})$, and thus decreases $\mathrm{HCl}(\mathrm{g})$. However, $\mathrm{KCl}(\mathrm{g})$ and $\mathrm{KOH}(\mathrm{g})$ increase substantially and $\mathrm{NaCl}(\mathrm{g})$ decreases a little. The reason is $\mathrm{Ca}$ addition absorbs $\mathrm{Si}$ to form $\mathrm{CaSiO}_{3}(\mathrm{~s})$, which reduces the amount of $\mathrm{KAlSi}_{2} \mathrm{O}_{6}(\mathrm{~s})$, thus induces the release of $\mathrm{KCl}(\mathrm{g})$ and $\mathrm{KOH}(\mathrm{g})$. Therefore, desulfurization by $\mathrm{CaO}$ may enhance the risk of deposition and corrosion due to the existence of alkali metals.

Considering that the temperature lies within 1073-1273 K during the experiments, $1200 \mathrm{~K}$ is chosen as the reaction temperature. Fig. 8 shows the effect of cornstalk fraction and $\mathrm{Ca} /(\mathrm{S}+0.5 \mathrm{Cl})$ ratio on the release of $\mathrm{SO}_{2} / \mathrm{HCl} / \mathrm{NaCl} / \mathrm{KCl}$. Fig. 8(a) indicates that $\mathrm{SO}_{2}$ emission decreases with increasing cornstalk fraction. This may due to the lower content of $\mathrm{S}$ and high content of $\mathrm{K}$ in cornstalk, and $\mathrm{S}$ is easy to retain in ash as $\mathrm{K}_{2} \mathrm{SO}_{4}(\mathrm{~s})$. $\mathrm{HCl}$ emission increases nearly linearly with increasing cornstalk fraction because of the higher $\mathrm{Cl}$ content in cornstalk. It shows that $\mathrm{KCl}$ is the main component involving alkali metals and $\mathrm{Cl}$, and increasing cornstalk fraction promotes the release of $\mathrm{KCl}(\mathrm{g})$ obviously. In Fig. 8(b), Ca addition decreases $\mathrm{HCl}(\mathrm{g})$, not forming $\mathrm{CaCl}_{2}(\mathrm{~s})$ in ash, but releasing more $\mathrm{KCl}(\mathrm{g})$ and $\mathrm{NaCl}(\mathrm{g})$. And Ca addition effectively reduces the emission of $\mathrm{SO}_{2}$ due to the formation of $\mathrm{CaSO}_{4}(\mathrm{~s})$.

Fig. 9 indicates the effect of $\mathrm{Ca} /(\mathrm{S}+0.5 \mathrm{Cl})$ ratio on the release of $\mathrm{SO}_{2} / \mathrm{HCl} / \mathrm{NaCl} / \mathrm{KCl}$. Increasing $\mathrm{Ca}$ fraction implies a decrease in $\mathrm{SO}_{2}$ emission due to the formation of $\mathrm{CaSO}_{4}(\mathrm{~s})$. The reason for the decrease of $\mathrm{HCl}(\mathrm{g})$ is that more $\mathrm{KCl}(\mathrm{g})$ and $\mathrm{NaCl}(\mathrm{g})$ are formed with increasing $\mathrm{Ca} /(\mathrm{S}+0.5 \mathrm{Cl})$ ratio. Since the formation of $\mathrm{CaSiO}_{3}(\mathrm{~s})$ will consume $\mathrm{Si}$ in cornstalk and results in the reduction of $\mathrm{KAlSi}_{2} \mathrm{O}_{6}(\mathrm{~s})$, we should consider $\mathrm{Ca}$ additive, as one way to control the formation of gaseous $\mathrm{SO}_{2}$ and $\mathrm{HCl}$ carefully in practical combustion, especially when the alkali metals in the fuel are relatively rich. 


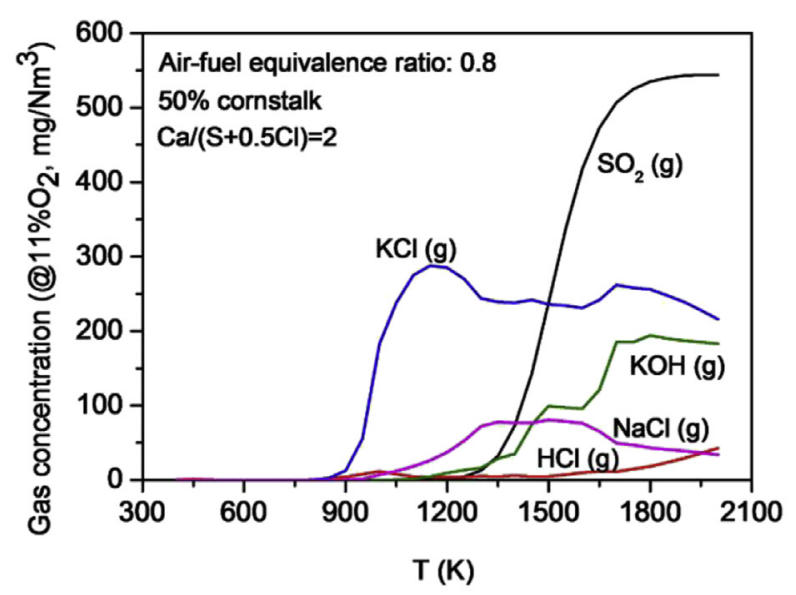

(a)

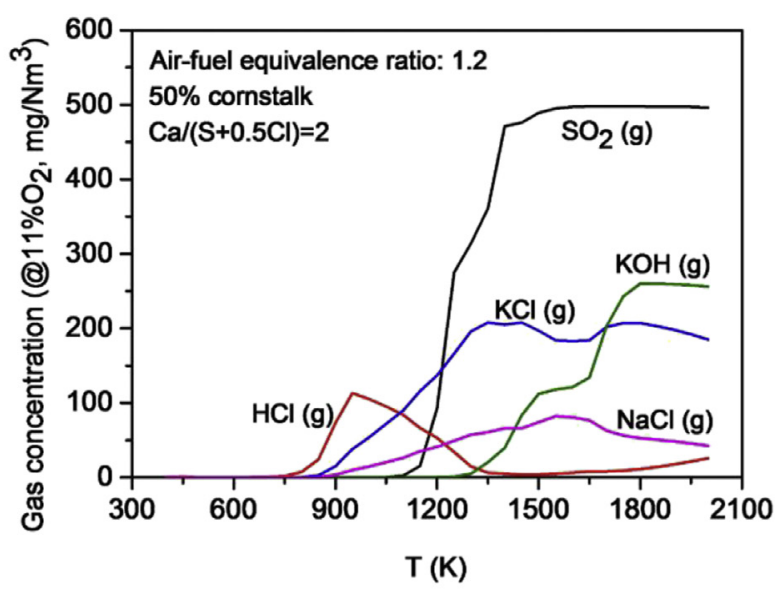

(b)

Fig. 7. Release of alkali metals in co-firing cornstalk and coal with calcium addition.

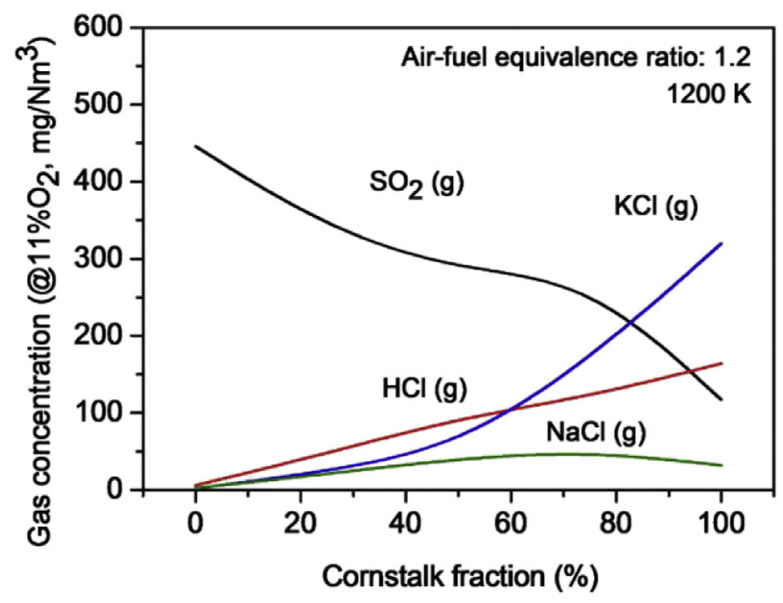

(a)

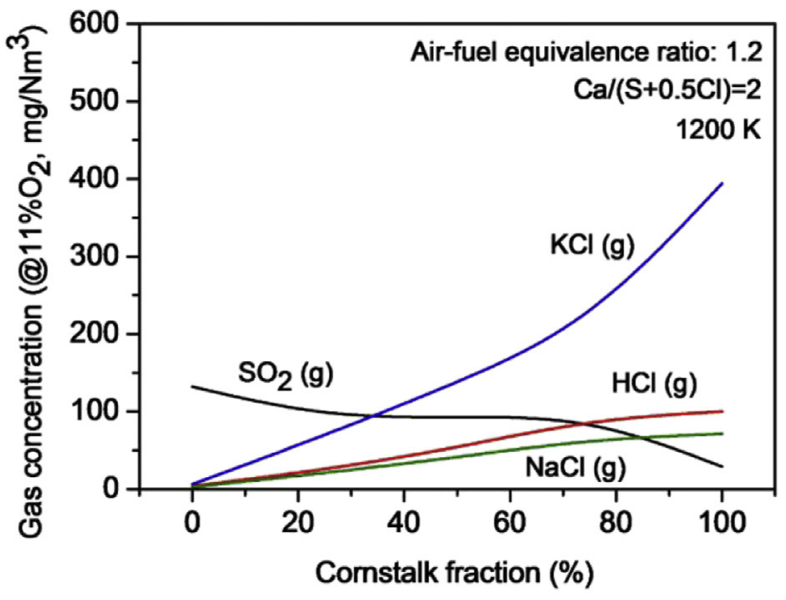

(b)

Fig. 8. Effect of cornstalk fraction and $\mathrm{Ca} /(\mathrm{S}+0.5 \mathrm{Cl})$ ratio on the release of alkali metals.

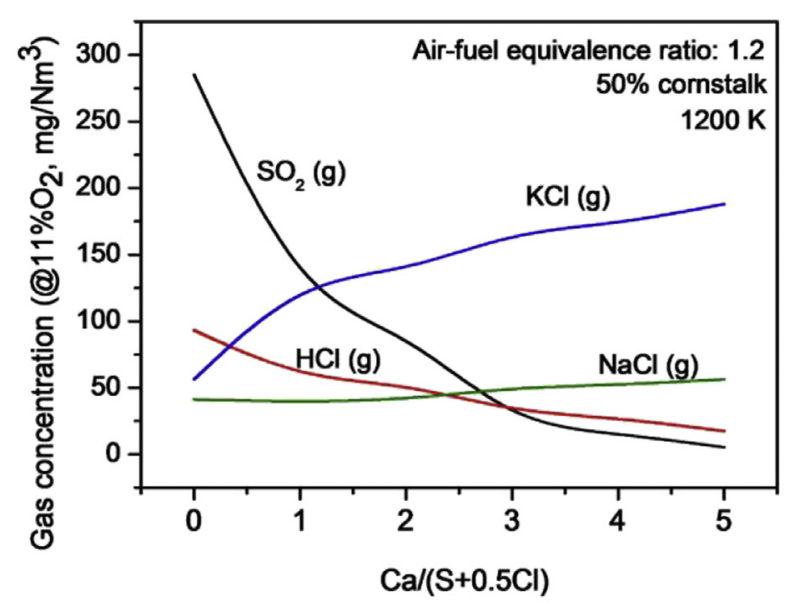

(a) $50 \%$ cornstalk

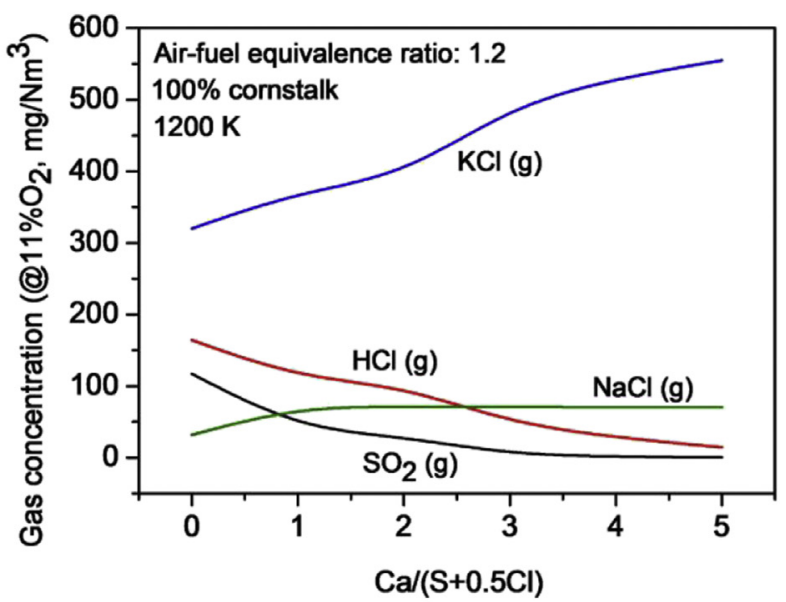

(b) $100 \%$ cornstalk

Fig. 9. Effect of $\mathrm{Ca} /(\mathrm{S}+0.5 \mathrm{Cl})$ ratio on the release of alkali metals during co-firing cornstalk and coal. 


\section{Conclusions}

Biomass contains high quantities of $\mathrm{K}, \mathrm{Na}$, and $\mathrm{Cl}$ compared with coal. In the paper, the release of alkali metals is investigated by ash element measurement and chemical equilibrium calculation during the co-firing of cornstalk derived fuel and coal. The synergistic effect on alkali metal release is investigated during the cocombustion. Besides the inherent mineral elements (e.g. Al, Si, etc.), the effect of $\mathrm{CaO}$ additive on alkali metal release is also investigated.

The experiments are operated under different mass blending fraction and temperature conditions. With increasing cornstalk fraction, the normalized ash content decreases according to a quadratic curve because the formation of alkali aluminosilicate may result in more elements being retained in ash. Similarly, the release ratios of $\mathrm{K}, \mathrm{Na}$, and $\mathrm{S}$ do not change linearly with the variation of cornstalk fraction either, which are suppressed significantly by the interaction of biomass and coal ashes. For the effect of $\mathrm{CaO}$ additive, the release ratios of $\mathrm{K}$ and $\mathrm{Na}$ increase with the enhancement of $\mathrm{CaO}$ addition.

The equilibrium analysis is used to predict and evaluate the release of alkali metals during the co-firing of biomass and coal. The release of alkali metals enhances with increasing temperature and cornstalk fraction. For silicon-lean blending fuels, such as coal and cornstalk derived fuel, adding Ca will decrease $\mathrm{HCl}(\mathrm{g})$ and release more $\mathrm{KCl}(\mathrm{g})$ and $\mathrm{KOH}(\mathrm{g})$ under both fuel-rich and air-rich conditions. More $\mathrm{KCl}(\mathrm{g})$ and $\mathrm{NaCl}(\mathrm{g})$ will be formed with increasing $\mathrm{Ca} /$ $(\mathrm{S}+0.5 \mathrm{Cl})$ ratio due to the formation of $\mathrm{CaSiO}_{3}(\mathrm{~s})$ and the reduction of alkali aluminosilicate.

\section{Acknowledgments}

Financial support by the Chinese Natural Science Foundation (No. 91130028 \& No. 51006115) is gratefully acknowledged. The authors also thank Mr. Hongming Jiang, Dr. Xiaofeng Guo, as well as Prof. Qinggang Lv and Yongjie Na for their help on this work.

\section{References}

[1] X. Liu, M.Q. Chen, Y.H. Wei, Combustion behavior of corncob/bituminous coal and hardwood/bituminous coal, Renew. Energy 81 (2015) 355-365.

[2] L.L. Baxter, Biomass-coal co-combustion: opportunity for affordable renewable energy, Fuel 84 (2005) 1295-1302.

[3] J. Li, A. Brzdekiewicz, W.H. Yang, W. Blasiak, Co-firing based on biomass torrefaction in a pulverized coal boiler with aim of $100 \%$ fuel switching, Appl. Energy 99 (2012) 344-354.

[4] H. Haykiri-Acma, S. Yaman, Interaction between biomass and different rank coals during co-pyrolysis, Renew. Energy 35 (2010) 288-292.

[5] P. Basu, J. Butler, M.A. Leon, Biomass co-firing options on the emission reduction and electricity generation costs in coal-fired power plants, Renew. Energy 36 (2011) 282-288.

[6] X.B. Wang, H.Z. Tan, Y.Q. Niu, M. Pourkashanian, L. Ma, E.Q. Chen, Y. Liu, Z.N. Liu, T.M. Xu, Experimental investigation on biomass co-firing in a 300 MW pulverized coal-fired utility furnace in China, Proc. Combust. Inst. 33 (2011) 2725-2733

[7] S.S. Daood, M.T. Javed, B.M. Gibbs, W. Nimmo, $\mathrm{NO}_{\mathrm{x}}$ control in coal combustion by combining biomass co-firing, oxygen enrichment and SNCR, Fuel 105 (2013) 283-292.

[8] S. Munir, W. Nimmo, B.M. Gibbs, The effect of air staged, co-combustion of pulverised coal and biomass blends on $\mathrm{NO}_{\mathrm{x}}$ emissions and combustion efficiency, Fuel 90 (2011) 126-135.

[9] J. Li, X.L. Zhang, W.H. Yang, W. Blasiak, Effects of flue gas internal recirculation on $\mathrm{NO}_{\mathrm{x}}$ and $\mathrm{SO}_{\mathrm{x}}$ emissions in a co-firing boiler, Int. J. Clean Coal Energy 2 (2013) 13-21.
[10] H.P. Nielsen, F.J. Frandsen, K. Dam-Johansen, L.L. Baxter, The implications of chlorine-associated corrosion on the operation of biomass-fired boilers, Prog. Energy Combust. Sci. 26 (2000) 283-298.

[11] I. Pisa, G. Lazaroiu, Influence of co-combustion of coal/biomass on the corrosion, Fuel Process. Technol. 104 (2012) 356-364.

[12] G.J. Zhang, M. Reinmöller, M. Klinger, Bernd Meyer, Ash melting behavior and slag infiltration into alumina refractory simulating co-gasification of coal and biomass, Fuel 139 (2015) 457-465.

[13] P. Teixeira, H. Lopes, I. Gulyurtlu, N. Lapa, P. Abelha, Evaluation of slagging and fouling tendency during biomass co-firing with coal in a fluidized bed, Biomass Bioenergy 39 (2012) 192-203.

[14] A. Fuller, M. Carbo, P. Savat, J. Kalivodova, J. Maier, G. Scheffknecht, Results of fly ash quality for disposal options from high thermal shares up to pure biomass combustion in a pilot-scale and large scale pulverized fuel power plant, Renew. Energy 75 (2015) 899-910.

[15] A. Magdziarz, M. Wilk, Thermogravimetric study of biomass, sewage sludge and coal combustion, Energy Convers. Manag. 75 (2013) 425-430.

[16] D. Nordgren, H. Hedman, N. Padban, D. Boström, Marcus Öhman, Ash transformations in pulverised fuel co-combustion of straw and woody biomass, Fuel Process. Technol. 105 (2015) 52-58.

[17] A.U. Syed, N.J. Simms, J.E. Oakey, Fireside corrosion of superheaters: effects of air and oxy-firing of coal and biomass, Fuel 101 (2012) 62-73.

[18] J. Han, M.H. Xu, H. Yao, M. Furuuchi, T. Sakano, H.J. Kim, Influence of calcium chloride on the thermal behavior of heavy and alkali metals in sewage sludge incineration, Waste Manag. 28 (2008) 833-839.

[19] R.D. Li, X.P. Kai, T.H. Yang, Y. Sun, Y.G. He, S.Q. Shen, Release and transformation of alkali metals during co-combustion of coal and sulfur-rich wheat straw, Energy Convers. Manag. 83 (2014) 197-202.

[20] Y.Q. Niu, Y.M. Zhu, H.Z. Tan, X.B. Wang, S.E. Hui, W.Z. Du, Experimental study on the coexistent dual slagging in biomass-fired furnaces: alkali- and silicate melt-induced slagging, Proc. Combust. Inst. 35 (2015) 2405-2413.

[21] R.R. Xiao, X.L. Chen, F.C. Wang, G.S. Yu, The physicochemical properties of different biomass ashes at different ashing temperature, Renew. Energy 36 (2011) 244-249.

[22] P. Monkhouse, On-line spectroscopic and spectrometric methods for the determination of metal species in industrial processes, Prog. Energy Combust. Sci. 37 (2011) 125-171.

[23] D. Porbatzki, M. Stemmler, M. Müller, Release of inorganic trace elements during gasification of wood, straw, and miscanthus, Biomass Bioenergy 35 (2011) 579-586.

[24] C. Erbel, M. Mayerhofer, P. Monkhouse, M. Gaderer, H. Spliethoff, Continuous in situ measurements of alkali species in the gasification of biomass, Proc. Combust. Inst. 34 (2013) 2331-2338.

[25] H. Fatehi, Y. He, Z. Wang, Z.S. Li, X.S. Bai, M. Aldén, K.F. Cen, LIBS measurements and numerical studies of potassium release during biomass gasification, Proc. Combust. Inst. 35 (2015) 2389-2396.

[26] C. Forsberg, M. Broström, R. Backman, E. Edvardsson, S. Badiei, M. Berg, H. Kassman, Principle, calibration, and application of the in situ alkali chloride monitor, Rev. Sci. Instrum. (2009) 80, 023104.

[27] T.H. Yang, X.P. Kai, Y. Sun, Y.G. He, R.D. Li, The effect of coal sulfur on the behavior of alkali metals during co-firing biomass and coal, Fuel 90 (2011) 2454-2460.

[28] A. Novakovic, S.C. van Lith, F.J. Frandsen, P.A. Jensen, L.B. Holgersen, Release of potassium from the systems K-Ca-Si and K-Ca-P, Energy \& Fuels 23 (7) (2009) 3423-3428.

[29] M.U. Rahim, X.P. Gao, H.W. Wu, Release of chlorine from the slow pyrolysis of $\mathrm{NaCl}$-loaded cellulose at low temperature, Proc. Combust. Inst. 35 (2015) 2891-2896.

[30] J.M. Johansen, M. Aho, K. Paakkinen, R. Taipale, H. Egsgaard, J.G. Jakobsen, F.J. Frandsen, P. Glarborg, Release of $\mathrm{K}, \mathrm{Cl}$, and S during combustion and cocombustion with wood of high-chlorine biomass in bench and pilot scale fuel beds, Proc. Combust. Inst. 34 (2013) 2363-2372.

[31] W.Q. Li, L.Y. Wang, Y. Qiao, J.Y. Lin, M.J. Wang, L.P. Chang, Effect of atmosphere on the release behavior of alkali and alkaline earth metals during coal oxy-fuel combustion, Fuel 139 (2015) 164-170.

[32] D.C. Dayton, D. Belle-Oudry, A. Nordin, Effect of coal minerals on chlorine and alkali metals released during biomass/coal cofiring, Energy \& Fuels 13 (1999) 1203-1211.

[33] FJ. Frandsen, K. Dam-Johansen, P. Rasmussen, Trace elements from combustion and gasification of coal-an equilibrium approach, Prog. Energy Combust. Sci. 20 (1994) 115-138.

[34] R. Yan, D. Gauthier, G. Flamant, J.M. Badie, Thermodynamic study of the behaviour of minor coal elements and their affinities to sulphur during coal combustion, Fuel 78 (1999) 1817-1829. 